\title{
A FOURTEEN-YEAR RETROSPECTIVE OF CLINIC-EPIDEMIOLOGICAL ASPECTS OF CUTANEOUS AND VISCERAL LEISHMANIASIS IN UBERLÂNDIA, MINAS GERAIS, BRAZIL
}

\author{
UMA RETROSPECTIVA DE 14 ANOS DOS ASPECTOS CLÍNICO- \\ EPIDEMIOLÓGICOS DA LEISHMANIOSE CUTÂNEA E VISCERAL EM \\ UBERLÂNDIA, MINAS GERAIS, BRASIL
}

\begin{abstract}
Túlio Teixeira ARAÚJO' ${ }^{1}$; Débora Cristina de Oliveira NUNES ${ }^{2,3}$
1. Faculdade de Medicina, Universidade Federal de Uberlândia, UFU, Uberlândia, MG, Brazil; 2. Instituto de Ciências Biomédicas, Universidade Federal de Uberlândia, UFU, Uberlândia, MG, Brazil; 3 Instituto Federal de Educação, Ciência e Tecnologia do Triângulo Mineiro, IFTM, Patrocínio, MG, Brazil. nunesdco@yahoo.com.br
\end{abstract}

\begin{abstract}
The purpose of this study was to describe clinic-epidemiological characteristics of leishmaniasis cases attended at the Clinical Hospital of Federal University of Uberlândia (CHU), state of Minas Gerais, from January 2000 to December 2013. This is a descriptive and retrospective review of medical records of patients diagnosed with leishmaniasis and treated at the CHU. 168 cases of leishmaniasis were analyzed and most patients were male, aged 23 to 60 years. For cutaneous and mucosal leishmaniasis, single lesions, located mainly in lower limbs and head (CL) and nasal mucosa (ML), were the most common clinical presentation. Regarding the diagnosis, the most performed methods for CL and ML were biopsy plus histopathology and biopsy plus immunohistochemistry; biopsy plus direct parasitological examination methods were the most frequent for VL. Most patients (84\%) received treatment, mainly glucantime for both CL and ML; VL treatment was based on amphotericin B or glucantime. According to data from Sistema de Informações de Agravos de Notificação (SINAN), the Brazilian information system to notify and investigate cases of diseases and their aggravations, no case has been confirmed as autochthonous. It is noteworthy the underreporting of cases and the lack of complete information in medical records. Our results may contribute to a better understanding of the real situation in Uberlândia region concerning to leishmaniasis.
\end{abstract}

KEYWORDS: Epidemiology. Leishmaniasis. Triângulo Mineiro. Uberlândia.

\section{INTRODUCTION}

Leishmaniasis is a complex of infectious, non-contagious and vector-transmitted diseases caused by an intracellular protozoan of the Leishmania genus (BRASIL, 2013; 2014). It is considered to be a Neglected Tropical Disease, due to affect the poorest people, the high prevalence in tropical regions and the lack of control and/or drug availability (LINDOSO, LINDOSO, 2009). This disease represents an important public health problem since it causes disability and disfigurement, along with economical, social and political impacts (LINDOSO, LINDOSO, 2009). It is still difficult to provide estimates of the actual number of infected people considering the lack of surveillance systems and the frequency of misdiagnosis and nondiagnosis (PACE, 2014). In Brazil, leishmaniasis reporting is compulsory when cases of cutaneous/mucosal and visceral leishmaniasis are confirmed (CL/ML and VL) and when there is a suspicion for VL (BRASIL, 2013; 2014). The notifications are made through the Information System for Notifiable Diseases (Sistema de Informação de Agravos de Notificação - SINAN), which codifies patient's sex and age, clinical manifestations and other relevant information.

Despite the underreporting, Brazil has a large number of cases of leishmaniasis, especially in the North, Central-West and Northeast regions of the country (COSTA, 2005; BRASIL, 2014). In the state of Minas Gerais, cutaneous leishmaniasis (CL) occurs from the middle of the past century with outbreaks related to deforestation and road construction, as well as the development of agriculture (FURTADO et al., 1966). From 1981 to 1986, 14 human cases were reported in Triângulo Mineiro and Alto Paranaíba regions (MACHADO et al., 1988; NISHIOKA et al., 1988). In 1987, there was a rapid emergence of cases, featuring a microepidemic of $\mathrm{CL}$ in Triângulo Mineiro and Alto Paranaíba, especially in Uberlândia and Indianópolis cities (MACHADO et al., 1992). Due to this outbreak, there were studies investigating the natural infection in dogs in rural and urban areas of Uberlândia and Coromandel cities. The researchers found that the canine infection in the region was active and thereby, the dog could play an important role as a reservoir of the disease. Furthermore, they may spread and form new endemic outbreaks in 
urban areas (MAYWALD et al., 1993; 1996). Other studies have identified the presence of phlebotomines responsible for the leishmaniasis transmission on the banks of Araguari river basin (LEMOS; LIMA, 2005; PAULA et al., 2013), in the urban area of Uberlândia (PAULA et al., 2008) and in the Sabiá Park, in Uberlândia. (RODRIGUES et al., 2011). Since 1992 there is no record of human leishmaniasis cases occurred in Triângulo Mineiro region and it is essential to know the epidemiological profile of the disease, as it makes possible to identify needs and propose solutions to problems, leading to health actions. Considering the relevance of such information, the purpose of this study was to describe the clinic-epidemiological aspects of leishmaniasis in Uberlândia from 2000 to 2013.

\section{MATERIAL AND METHODS}

The study is a descriptive and retrospective review of 168 medical reports with confirmed diagnosis of leishmaniasis (visceral - VL, cutaneous - CL or mucosal - ML) treated at the Clinical Hospital of Federal University of Uberlândia (CHU), state of Minas Gerais, Brazil. Initially, medical reports were searched according to the International Code of Diseases (ICD) - research of Leishmaniasis, Tegumentary/Cutaneous Leishmaniasis or Visceral Leishmaniasis - from January 2000 to December 2013, then excluding from the analysis incomplete records and standardizing the data extraction by using a form. The following patient variables analyzed were age, sex, city of residence, occupation, risk behavior, clinical manifestations (including lesion features, number, anatomic distribution and time evolution, if it is a tegumentary form), case origin (autochthonous or imported), signs/symptoms, diagnosis, treatment (including the drug used, duration of treatment, side effects), outcome of the case, and notification data. Information obtained in medical reports was tabulated and analyzed using Microsoft Excel. Further, the data from CHU medical records were confronted with the data reported by the local epidemiological surveillance (SINAN). The study was approved by the Research Ethics Committee of Federal University of Uberlândia - CEP/UFU (Plataforma Brasil, process 529.153/2014).

$\mathrm{CHU}$ is the biggest service provider accredited by the Unified Health System (SUS) in the state of Minas Gerais, and sixth in the ranking of largest university hospitals registered in Ministry of Education (MEC). It is a reference in medium and high complexity, delivering services to a population of nearly three million people in 86 districts of Triângulo Mineiro and Alto Paranaíba regions (HC UFU, 2016).

\section{RESULTS AND DISCUSSION}

Epidemiological analyses are important tools for the choice of appropriate leishmaniasis control strategies for each geographical region. It is important to get data that report diverse aspects such as: (1) human cases (incidence, clinical form of the disease, sex, age and others); (2) transmission dynamics, entomological studies to define the vector and animal reservoirs; (3) parasitological studies to describe the species of etiological agents that circulate in the focus of transmission; and (4) ecological aspects of the vector and of the animal reservoirs involved (MARZOCHI; MARZOCHI, 1994). In our study, we described clinical and epidemiological aspects of human leishmaniasis cases attended at the Clinical Hospital of Federal University of Uberlândia (CHU) from January 2000 to December 2013. In CHU, leishmaniasis has been monitored since 2005 when it was created the epidemiological surveillance center of the hospital (HC UFU, 2016).

During the fourteen years covered by this research, a total of 168 cases diagnosed as leishmaniasis were registered; there were 58 cases of CL, 50 of ML and 60 of VL. Figure 1 shows the distribution of leishmaniasis cases according to the month and year of the notification reports. Analyzing each type of leishmaniasis, CL had high incidence between 2010 and 2012 and ML had an increase from 2004 to 2007. The incidence of VL remained low until 2007; from 2008 on, there was an increase in the number of cases. In the present study, we observed that patients from several nearby locations were treated at CHU (Abadia dos Dourados, Araguari, Cachoeira Dourada, Campina Verde, Canápolis, Coromandel, Estrela do Sul, Ituiutaba, Monte Alegre, Monte Carmelo, Paracatu, Patrocínio, Prata, Presidente Olegário, Tupaciguara, Uberlândia). The number of leishmaniasis cases in Uberlândia is lower than in the state of Minas Gerais. But it is important to highlight that we found $59 \%$ of underreported cases (Table 1), probably due to the fact that the epidemiological surveillance center of the hospital was created only in 2005. Moreover, it is through the notifications, mandatory since 1975, that the epidemiological surveillance quantifies cases of the disease and communicate to the Ministry of Health. Regarding this data analysis, the situation of each locality is evaluated and 
necessary resources to control the disease are provided. The failure of this procedure implies a lack of resources for the institution, what could make worse the already precarious financial conditions of public hospitals (DAMASCENO, 2006).

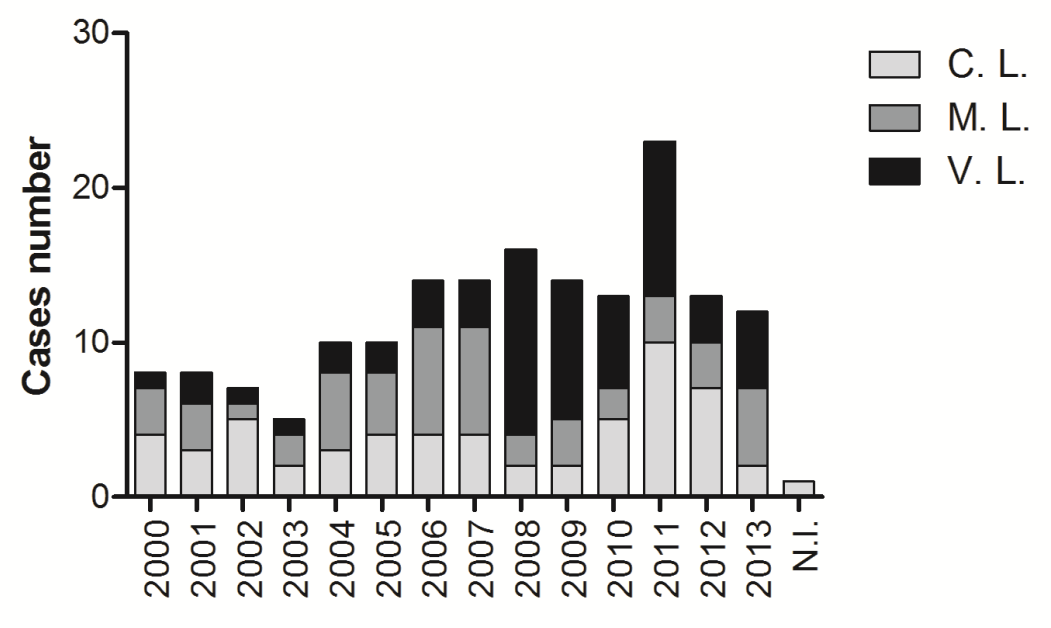

\section{Year}

Figure 1. Annual distribution of leishmaniasis cases, Uberlândia municipality, 2000-2013.CL - Cutaneous Leishmaniasis; ML - Mucosal Leishmaniasis; VL - Visceral Leishmaniasis. N. I. : Not Informed.

Out of 168 cases, patients aged 23-60 years were the most affected in all types of leishmaniasis and the sex ratio was 3.42 (male:female); for each type of leishmaniasis, male were primarily affected, similarly to other investigations (MONTEIRO et al., 2009; CELLA et al., 2012). Regarding the individual's occupation, 44 were rural workers (especially in agriculture and mining), 33 were children and retired, 10 were domestic workers, 9 were students, 44 were patients who performed various activities (general services, mechanics, driving, masonry, commerce, banking and others) and 26 did not inform (Table 1). Associating the age group with risk, it was observed the high prevalence of risk situations (rural work and traveling to endemic areas) associated with the most affected age range. The affected age (23-60 years) corresponds to the economically active population, which is mostly constituted by rural workers who are more exposed to the vectors during their daily activities. This finding is not a peculiarity of our study and confirms data previously reported in several studies in different locations (JONES et al., 1987; TOLEZANO, 1994; MARTINS et al., 2004; CURTI et al., 2009; CELLA et al., 2012; JIMANUS et al., 2012).

Table 1. Leishmaniasis victims according to sex, age, occupational activity, risk and SINAN notification, in Uberlândia municipality, 2000-2013. CL - Cutaneous Leishmaniasis; ML - Mucosal Leishmaniasis; VL - Visceral Leishmaniasis.

\begin{tabular}{|c|c|c|c|c|c|}
\hline \multirow[t]{2}{*}{ Characteristics } & \multicolumn{5}{|l|}{ Cases } \\
\hline & CL* & ML** & VL**** & $\mathbf{N}$ & $\%$ \\
\hline \multicolumn{6}{|l|}{ Gender } \\
\hline Female & 9 & 12 & 17 & 38 & 22.62 \\
\hline Male & 49 & 38 & 43 & 130 & 77.38 \\
\hline \multicolumn{6}{|c|}{ Age range (years) } \\
\hline $0-2$ & 1 & 0 & 16 & 17 & 10.12 \\
\hline $3-13$ & 6 & 1 & 7 & 14 & 8.33 \\
\hline $14-22$ & 5 & 3 & 3 & 11 & 6.55 \\
\hline $23-60$ & 43 & 31 & 29 & 103 & 61.31 \\
\hline$>60$ & 3 & 14 & 5 & 22 & 13.10 \\
\hline
\end{tabular}




\begin{tabular}{llllll}
\hline $\begin{array}{l}\text { Not informed } \\
\text { Occupational activity }\end{array}$ & 0 & 1 & 0 & 1 & 0.60 \\
Rural worker & 18 & 15 & 11 & 44 & 26.19 \\
Student & 6 & 1 & 2 & 9 & 5.36 \\
Domestic worker & 1 & 6 & 3 & 10 & 5.95 \\
Children and retired & 5 & 6 & 22 & 33 & 19.64 \\
Unrelated activities & 16 & 12 & 18 & 46 & 27.38 \\
Not informed & 12 & 10 & 4 & 26 & 15.48 \\
Risk & & & & & \\
No & 25 & 28 & 26 & 79 & 47.02 \\
Rural area contact & 13 & 9 & 10 & 32 & 19.05 \\
Travel to endemic area & 11 & 3 & 6 & 20 & 11.90 \\
Other & 2 & 0 & 5 & 7 & 4.17 \\
Not informed & 7 & 10 & 13 & 30 & 17.86 \\
SINAN notification & & & & & \\
No & 41 & 39 & 19 & 99 & 58.93 \\
Yes & 17 & 11 & 41 & 69 & 41.07 \\
Not informed & 0 & 0 & 0 & 0 & 0.00 \\
Total & 58 & 50 & 60 & 168 & 100 \\
\hline
\end{tabular}

Considering clinical aspects of CL e ML (Table 2), lesions showed up single in $29 \mathrm{CL}$ patients and multiple in 26. In ML, the lesions were shown up single in 31 patients and multiple in 18. This trend to a lower number of lesions per patient with a high frequency of single lesions, has already been seen by other authors (NAME et al., 2005; SKRABA et al., 2006; MURBACK et al., 2011; CELLA et al., 2012). By checking the time evolution of the lesions at the medical records, it was appointed that most of them presented more than 60 days ( 28 cases for CL and 24 cases for ML) and that a large number of cases did not inform the time evolution (Table 2). Over 60 days, CL lesions showed up advanced and crusty in ulcerative form, what is reported as classic and prevalent in the literature (MURBACK et al., 2011). ML patients presented complications such as septum and palatal perforation. The data show compatibility with the natural evolution of disease, proving that delays in diagnosis can lead to severe forms of the disease with disfiguring lesions, and further, economic and psychological consequences (GREVELINK; LERNER, 1996; PASTORINO et al., 2002). In addition, such advanced lesions are potentially dangerous, because besides causing permanent damage, they often suffer secondary contamination by bacteria, what demands a special local care. The anatomical distribution of the lesions was classified as head, trunk, lower limbs, upper limbs, oral mucosa, nasal mucosa and others. From the CL analysis, 70 anatomical regions were reported because, in some cases, lesions were disseminated over the patient's body. Most cases of CL affected lower limbs, followed by the head, upper limbs and trunk, similar to what has been observed by another researchers (CASTRO et al., 2002; OLIVEIRA et al., 2004; MURBACK et al., 2011; CELLA et al., 2012). In ML, the nasal mucosal was the main anatomical region affected (56\%). This high incidence of lesions in exposed areas of the body corresponds to the main area of sting by insect vectors containing parasites.

In relation to the symptoms (Table 3 ), it is noteworthy the lack of information of CL, since 34 patients had not their symptoms informed; other patients presented specific symptoms including itching, paresthesia and nodular lesion or even general symptoms such as nausea, vomiting and fever. The nasal and oropharyngeal symptoms (itching, sore throat, nasal obstruction and local perforation) predominated in cases of ML (74\%). In $\mathrm{VL}$, it highlights the presence of specific signs and symptoms such as fever, hepatosplenomegaly, abdominal pain and weight loss. 
Table 2. Clinical characteristics of the lesions presented by patients diagnosed with tegumentar leishmaniasis (cutaneous and mucosa), from 2000 to 2013.

\begin{tabular}{|c|c|c|c|c|}
\hline \multirow{3}{*}{ Characteristics } & \multicolumn{4}{|c|}{ Cases } \\
\hline & \multicolumn{2}{|c|}{$C L$} & \multicolumn{2}{|c|}{$M L$} \\
\hline & $N$ & $\%$ & $N$ & $\%$ \\
\hline \multicolumn{5}{|c|}{ Number os lesions } \\
\hline Single & 29 & 50.00 & 31 & 62.00 \\
\hline Multiple & 26 & 44.83 & 18 & 36.00 \\
\hline Not informed & 3 & 5.17 & 1 & 2.00 \\
\hline \multicolumn{5}{|c|}{ Time evolution of lesion (days) } \\
\hline $0-30$ & 2 & 3.45 & 1 & 2.00 \\
\hline $31-60$ & 9 & 15.52 & 1 & 2.00 \\
\hline$>60$ & 28 & 48.28 & 24 & 48.00 \\
\hline Not informed & 19 & 32.76 & 24 & 48.00 \\
\hline Total & 58 & 100 & 50 & 100 \\
\hline \multicolumn{5}{|c|}{ Anatomical region } \\
\hline Head & 17 & 24.29 & & \\
\hline Upper limbs & 14 & 20.00 & & \\
\hline Lower limbs & 23 & 32.86 & & \\
\hline Trunck & 10 & 14.29 & & \\
\hline Oral mucosa & & & 13 & 32.73 \\
\hline Nasal mucosa & & & 36 & 56.36 \\
\hline Others & & & 5 & 9.09 \\
\hline Not informed & 6 & 8.57 & 1 & 1.82 \\
\hline Total & 70 & 100 & 50 & 100 \\
\hline
\end{tabular}

Table 3. Symptoms associated with Leishmaniasis, Uberlândia municipality, 2000-2013.

\begin{tabular}{|c|c|c|c|c|c|}
\hline \multirow[b]{2}{*}{ Symptomatology } & \multicolumn{3}{|c|}{ Cases } & \multirow[b]{2}{*}{$\mathbf{N}$} & \multirow[b]{2}{*}{$\%$} \\
\hline & $\mathbf{C L}$ & ML & VL & & \\
\hline Specific symtoms* & 14 & 37 & 55 & 106 & 63.1 \\
\hline General symptoms** & 10 & 6 & 4 & 20 & 11.9 \\
\hline Not informed & 34 & 7 & 1 & 42 & 25.00 \\
\hline Total & 58 & 50 & 60 & 168 & 100 \\
\hline
\end{tabular}

* Specific symptoms: cutaneous itching, paresthesia, nodular lesion related to CL; nasal itching, nasal obstruction and nasal perforation related to MC; 3 or more specific symptoms for VL such as fever, hepatosplenomegaly, abdominal pain and weight loss; ** General symptoms: nausea, vomiting, fever, bleeding for CL and ML; nausea, vomiting, cough, lack of appetite, asthenia for VL.

Regarding the diagnosis (Table 4), the most performed methods for CL and ML were biopsy followed by histopathology and biopsy followed by immunohistochemistry. The most frequent method for VL was biopsy followed by direct parasitological examination. In relation to the treatment (Table 4), about $84 \%$ of patients were treated and in $15.5 \%$ of the cases, there was not information about the treatment in medical records.
The diagnosis of CL and ML is clinical, with subsidiary laboratory tests, such as direct analysis of scraped or aspirated material from the lesion. For the VL diagnosis, the gold standard is to identify parasites in tissue smears, however, difficulties in obtaining tissues makes less invasive methods more used (DAVIES et al., 2003). Take into account that clinical aspects of leishmaniasis, the lack of information related to the symptoms in medical 
records affect all the cases management, since typical signs facilitate the diagnosis, which includes epidemiological, clinical and laboratorial aspects. In $\mathrm{VL}$, the presence of specific signs and symptoms, such as fever, splenomegaly and hepatomegaly accords to what is most frequently reported in clinical findings (CASCIO et al., 2002). Although typical symptoms predominated in $74 \%$ of $\mathrm{ML}$ cases, the time evolution of the lesions occurred during more than 60 days. It is interesting to inquire why patients who presented typical symptoms had a delayed diagnosis, what led to a worsening of the disease, with several cases of nasal septum perforation. This late diagnosis shows a nescience or even an unconcern by patients that do not seek for medical care, or negligence by health institutions in diagnosing and treating the disease (COELHO, 2010).

Table 4. Aspects related to diagnosis and treatment of Leishmaniasis, Uberlândia, 2000-2013.

\begin{tabular}{|c|c|c|c|c|c|}
\hline & Cases & & & & \\
\hline Characteristics & $\mathbf{C L}$ & ML & VL & $\mathbf{N}$ & $\%$ \\
\hline Diagnosis & & & & & \\
\hline Biopsy and histopathology & 13 & 14 & 0 & 27 & 16.07 \\
\hline Biopsy and immunohistochemistry & 22 & 14 & 13 & 49 & 29.17 \\
\hline Biopsy and direct parasitologic & 10 & 7 & 27 & 44 & 26.19 \\
\hline Clinic-epidemiological & 1 & 1 & 1 & 3 & 1.79 \\
\hline Serology & 3 & 5 & 2 & 10 & 5.95 \\
\hline Not informed & 9 & 9 & 17 & 35 & 20.83 \\
\hline Treatment & & & & & \\
\hline Treated & 51 & 44 & 46 & 141 & 83,93 \\
\hline Untreated & 1 & 0 & 0 & 1 & 0.59 \\
\hline Not informed & 6 & 6 & 14 & 26 & 15.48 \\
\hline Treatment drug & & & & & \\
\hline Amphotericin B & 6 & 11 & 28 & 45 & 26.79 \\
\hline Amphotericin B + Pentoxifylline & 0 & 1 & 0 & 1 & 0.60 \\
\hline Cephalexin & 1 & 0 & 0 & 1 & 0.60 \\
\hline Glucantime & 44 & 22 & 22 & 88 & 52.38 \\
\hline Glucantime + Pentoxifylline & 4 & 13 & 0 & 17 & 10.12 \\
\hline Not informed & 3 & 3 & 10 & 16 & 9.52 \\
\hline Total & 58 & 50 & 60 & 168 & 100 \\
\hline Side effects & & & & & \\
\hline Cardiotoxicity & 1 & 5 & 6 & 12 & 7.14 \\
\hline Hepatopancreatic function & 5 & 4 & 1 & 10 & 5.95 \\
\hline Nephrotoxicity & 3 & 3 & 2 & 11 & 6,55 \\
\hline General symptoms & 6 & 13 & 5 & 8 & 4,76 \\
\hline Other & 4 & 7 & 2 & 13 & 7.74 \\
\hline No & 34 & 17 & 29 & 80 & 47.62 \\
\hline Not informed & 9 & 8 & 17 & 34 & 20.24 \\
\hline Treatment duration & & & & & \\
\hline Mean period (days) & 22.24 & 21.82 & 21.98 & 21.76 & \\
\hline Maximum period (days) & 45 & 45 & 58 & 58 & \\
\hline
\end{tabular}

The most widely used treatment for both CL $(82.75 \%)$ and ML (70\%) was glucantime alone or in combination with pentoxifylline. In 28 cases of VL, treatment was attributed to amphotericin B (47\%) and in 22 cases, to glucantime (37\%). The time of treatment for all types of leishmaniasis lasted an average of 22 days. Most of patients did not present side effects; others presented general symptoms 
including nausea, vomiting, fever, diarrhea, constipation, dizziness and itching. Only a small portion of patients presented cardiotoxicity, followed by hepatopancreatitis and nephrotoxicity (Table 4). An amount of $84 \%$ of patients was treated. For CL and ML, glucantime alone or in combination with pentoxifylline was the most used drug. For VL, $47 \%$ of patients received amphotericin B and $37 \%$ were treated with glucantime. As recommended by the Ministry of Health, the first-choice drug for tegumentar leishmaniasis treatment is the pentavalent antimony $\left(\mathrm{Sb}^{\mathrm{V}}\right)$ (BRASIL, 2013). The combined use of pentoxifylline with antimony has significantly decreased the healing time of lesions, with no documented relapse during the two years of followup, what suggests the effectiveness of the antiinflammatory action of pentoxifylline in treating the disease (STRIETER et al., 1988). For VL, it is recommended both glucantime and amphotericin B and the choice of each of them should consider age, presence of comorbidities and pregnancy (BRASIL, 2014). Regarding pentavalent antimony, the outpatient treatment is possible, reducing the risks related to hospitalization. Amphotericin B is the only option in the treatment of pregnant women and patients who have contraindications, show toxicity or that are refractory to the use of pentavalent antimony (BRASIL, 2011). Analyzing the data from local epidemiological surveillance (SINAN), despite the side effects, the case evolution showed a high cure rate $(81 \%)$, and a ratio of only $1.8 \%$ related to death caused by the disease or treatment (data not shown). Serious side effects and the appearance of drug resistance contribute to difficulties and treatment failures (GUERIN et al., 2002). It is important to mention that among the 168 cases examined, none was confirmed as autochthonous according to SINAN forms.

Although no case examined in our study has been confirmed as autochthonous, leishmaniasis is still an important parasitic disease treated in CHU. It was observed that its occurrence has a strong relationship with occupational activities in rural environment or endemic areas, affecting mainly male rural workers. Another important aspect is the delay in seeking medical assistance, which leads to severe forms of the disease and difficulties to apply a treatment. Finally, the data presented failure in the investigation and notification of the disease, what corroborates the status of neglected disease. The underreporting of the epidemiological surveillance implicates an underestimated incidence to the government, what leads to lower resources than necessary to control the disease. Thus, our results may contribute for a better understanding of the real situation of leishmaniasis in Uberlândia region.

\section{ACKNOWLEDGEMENTS}

The authors are thankful to the Clinical Hospital of Federal University of Uberlândia for disposing medical records to analysis and to the local epidemiological surveillance (Vigilância Epidemiológica de Uberlândia, VIGEP) for disposing SINAN forms. The research did not receive funding.

RESUMO: O propósito desse estudo foi descrever as características clínico-epidemiológicas dos casos de leishmaniose atendidos no Hospital de Clínicas da Unversidade Federal de Uberlândia (HCU), Minas Gerais, de janeiro de 2000 a dezembro de 2013. Trata-se de uma revisão descritiva e retrospectiva de registros médicos de pacientes diagnosticados com leishmaniose e tratados no HCU. 168 casos diagnosticados com leishmaniose foram analisados e os pacientes, em sua marioria, foram homens, com idade entre 23 e 60 anos. Para a leishmaniose cutânea e mucosa, lesões únicas, localizadas principalmente nos membros inferiores e na cabeça (LC) e mucosa nasal (LM), foram as apresentações clínicas mais comuns. Em relação ao diagnóstico, os métodos mais realizados para LC e LM foram biópsia mais histopatologia e biópsia mais imunohistoquímica; biópsia mais parasitológico direto foi o mais frequente para LV. A maioria dos pacientes $(84 \%)$ recebeu tratamento, principalmente glucantime tanto para LC quanto para LM; o tratamento para LV foi atribuido à anfotericina $\mathrm{B}$ ou glucantime. De acordo com os dados do Sistema de Informação de Agravos de Notificação (SINAN), o sistema de informação brasileiro para notificar e investigar casos de doenças e seus agravamentos, nenhum caso foi confirmado como autóctone. Ressalta-se a subnotificação dos casos e a informação incompleta nos prontuários médicos. Nossos resultados podem contribuir para um melhor entendimento da real situação da leishmaniose na região de Uberlândia.

PALAVRAS-CHAVE: Epidemiologia. Leishmaniose. Triângulo Mineiro. Uberlândia. 


\section{REFERENCES}

BRASIL. Ministério da Saúde. Secretaria de Vigilância em Saúde. Departamento de Vigilância

Epidemiológica. Leishmaniose visceral : recomendações clínicas para redução da letalidade / Ministério da Saúde. Secretaria de Vigilância em Saúde. Departamento de Vigilância Epidemiológica. - Brasília: Ministério da Saúde, 2011.78 p. : il. - (Série A. Normas e Manuais Técnicos)

BRASIL. Ministério da Saúde. Secretaria de Vigilância em Saúde. Departamento de Vigilância Epidemiológica. Manual de Vigilância da Leishmaniose Tegumentar Americana/Ministério da Saúde, Secretaria de vigilância em Saúde, Departamento de Vigilância Epidemiológica. - 2 ed. atual., 3. reimpr. Brasília: Editora do Ministério da Saúde, 2013. 180 p.: il.

BRASIL. Ministério da Saúde. Secretaria de Vigilância em Saúde. Departamento de Vigilância Epidemiológica. Manual de vigilância e controle da leishmaniose visceral / Ministério da Saúde, Secretaria de Vigilância em Saúde, Departamento de Vigilância Epidemiológica. - 1. ed., 5. reimpr. Brasília : Ministério da Saúde, 2014. 120 p.: il.

CASCIO, A.; COLOMBA, C.; ANTINORI, S.; OROBELLO, M.; PATERSON, D.; TITONE, L. Pediatric visceral leishmaniasis in Western Sicily, Italy: a retrospective analysis of 111 cases. European Journal of Clinical Microbiology \& Infectious Diseases, Wiesbaden, v. 21, p. 277-282, 2002.

https://doi.org/10.1007/s10096-002-0707-3

CASTRO, E. A.; SOCCOL, V. T.; MEMBRIVE, N.; LUZ, E. Estudo das características epidemiológicas e clínicas de 332 casos de leishmaniose tegumentar notificados na região norte do Estado do Paraná de 1993 a 1998. Revista da Sociedade Brasileira de Medicina Tropical, Uberaba, v. 35, p. 445-452, 2002. https://doi.org/10.1590/S0037-86822002000500004

CELlA, W.; MELO, S. C. C. S.; DELL AGNOLO, C. M.; PELlOSO, S. M.; SILVEIRA, T. G. V.; CARVALHO, M. D. B. Seventeen years of American Cutaneous Leishmaniasis in a Southern Brazilian municipality. Revista do Instituto de Medicina Tropical de São Paulo, São Paulo, v. 54, n. 4, p. 215-218, 2012. https://doi.org/10.1590/S0036-46652012000400006

COELHO, Leíla Inês de Aguiar Raposo da Câmara. Caracterização de Leishmania spp em amostras isoladas de pacientes portadores de leishmaniose tegumentar americana em área endêmica da região norte, Brasil. 2010. 94f. Tese (Doutorado) - Fundação Oswaldo Cruz, 2010.

COSTA, J. M. L. Epidemiologia das leishmanioses no Brasil. Gazeta Médica da Bahia, Salvador, v. 75, p. 3$17,2005$.

CURTI, M. C. M.; SILVEIRA, T. G. V.; ARRAES, S. M. A. A.; BERTOLINI, D. A.; ZANZARINI, P. D.; VENAZZI, E. A. S. Aspectos epidemiológicos da leishmaniose tegumentar americana na Região Noroeste do Estado do Paraná. Revista de Ciências Farmacêuticas Básica e Aplicada, Araraquara, v. 30, p. 63-68, 2009.

DAMASCENO, M. C. T. Aspectos Ético-Legais no Pronto-Socorro. In: MARTINS, H. S.; DAMASCENO, M. C. T.; AWADA, S. B. (Ed.). Pronto Socorro - Condutas do Hospital das Clínicas da Faculdade de Medicina da Universidade de São Paulo. São Paulo: Manoele Ltda 2006. p. 16-22.

DAVIES, C. R.; KAYE, P.; CROFT, S. L.; SUNDAR, S. Leishmaniasis: new approaches to disease control. British Medical Journal, London, v. 326, p.377-382, 2003. https://doi.org/10.1136/bmj.326.7385.377

FURTADO, T.; ALEIXO, J.; LOPES, C. F. Surto de leishmaniose tegumentar americana em Minas Gerais. O Hospital, Rio de Janeiro, v. 70, p. 259-266, 1966.

GREVELINK, S. A.; LERNER, E. A. Leishmaniasis. Journal of the American Academy of Dermatology, Saint Louis, v. 34, n. 2, p. 257-72, 1996. https://doi.org/10.1016/S0190-9622(96)80121-6 
GUERIN, P. J.; OLLIARO, P.; SUNDAR, S.; BOELAERT, M.; CROFT, S. L.; DESJEUX, P.; WASUNNA, M. K.; BRYCESON, A. D. Visceral leishmaniasis: current status of control, diagnosis, and treatment, and a proposed research and development agenda. The Lancet Infectious Diseases, London, v. 2, p. 494-501, 2002. https://doi.org/10.1016/S1473-3099(02)00347-X

HC UFU: Available in http://www.hc.ufu.br/pagina/institucional (Access in 03/08/2016).

HC UFU: Available in http://www.hc.ufu.br/pagina/apresentacao (Access in 03/08/2016).

JIRMANUS, L.; GLESBY, M. J.; GUIMARÃES, L. H.; LAGO, E.; ROSA, M. E.; MACHADO, P. R.; CARVALHO, E. M. Epidemiological and clinical changes in American tegumentary leishmaniasis in an area of Leishmania (Viannia) braziliensis transmission over a 20-year period. The American Journal of Tropical Medicine and Hygiene, Mclean, v. 86, n. 3, p. 426-433, 2012. https://doi.org/10.4269/ajtmh.2012.11-0378

JONES, T. C.; JOHNSON, W. D.; BARRETO, A. C.; LAGO, E.; BADARO, R.; CERF, B. Epidemiology of American Cutaneous Leishmaniasis due to Leishmania braziliensis braziliensis. The Journal of Infectious Diseases, Chicago, v. 156, p. 73-83, 1987. https://doi.org/10.1093/infdis/156.1.73

LEMOS, J. C.; LIMA, S. C. Leishmaniose tegumentar americana: flebotomíneos em área de transmissão no Município de Uberlândia, MG. Revista da Sociedade Brasileira de Medicina Tropical, Uberaba, v. 38, n. 1, p. 22-26, 2005. https://doi.org/10.1590/S0037-86822005000100005

LINDOSO, J. A. L.; LINDOSO, A. A. B. P. Neglected tropical diseases in Brazil. Revista do Instituto de Medicina Tropical de São Paulo, São Paulo, v. 51, n. 5, p. 247-253, 2009. https://doi.org/10.1590/S003646652009000500003

MACHADO, M. I.; COSTA-CRUZ, J. M.; GONCALVES, M. R. F.; FERREIRA, M. S.; NISHIOKA, S. A. American Cutaneous Leishmaniasis (ACL) in Triângulo Mineiro e Alto Paranaíba, Minas Gerais: Parasitological diagnosis. Memórias do Instituto Oswaldo Cruz, Rio de Janeiro, v. 83, p. 44, 1988.

MACHADO, M. I.; NISHIOKA, S. A.; FERREIRA, M. S.; COSTA-CRUZ, J. M.; ROCHA, A.; SILVA, A. M.; SILVA, M.; GONCALVES-PIRES, M. R. F. Leishmaniose tegumentar americana no Triângulo Mineiro e Alto Paranaíba, Minas Gerais, Brasil: aspectos clinico-laboratoriais e epidemiologicos de uma microepidemia. Revista do Centro de Ciências Biomédicas da Universidade Federal de Uberlândia, Uberlândia, v. 8, n. 1, p. 17-28, 1992.

MARTINS, L. M.; REBÊLO, J. M. M.; DOS SANTOS, M. C. F. V.; COSTA, J. M. L.; DA SILVA, A. R.; FERREIRA, L. Ecoepidemiologia da leishmaniose tegumentar no Município de Buriticupu, Amazônia do Maranhão, Brasil, 1996 a 1998. Cadernos de Saúde Pública, Rio de Janeiro, v. 20, p. 735-743, 2004.

MARZOCHI, M. C. A.; MARZOCHI, K. B. F. Tegumentary and visceral leishmaniasis in Brazil - emerging anthropozoonosis and possibilities for their control. Cadernos de Saúde Pública, Rio de Janeiro, v. 10, p. 359375, 1994.

MAYWALD, P. G.; MACHADO, M. I.; CRUZ, J. M. C.; OLIVEIRA, M. G.; PIRES, M. R. F. G. Leishmaniose tegumentar canina: inquérito soroepidemiológico em áreas rural e urbana no município de Uberlândia, Minas Gerais. Brazilian Journal of Veterinary Research and Animal Science, São Paulo, v. 30, n. 1, p. 25-29, 1993. https://doi.org/10.11606/issn.1678-4456.bjvras.1993.52013

MAYWALD, P. G.; MACHADO, M. I.; COSTA-CRUZ, J. M.; GONÇALVES-PIRES, M. R. F. Leishmaniose tegumentar, visceral e doença de Chagas caninas em municípios do Triângulo Mineiro e Alto Paranaíba, Minas Gerais, Brasil. Cadernos de Saúde Pública, Rio de Janeiro, v. 12, n. 3, p. 321-328, 1996. 
MONTEIRO, W. M.; EITZKE-ABREN, H. C.; FERREIRA, M. E. M. C.; MELO, G. C.; BARBOSA, M. G. V.; LONARDONI, M. V. C.; SILVEIRA, T. G. V.; TEODORO, U. Mobilidade populacional e produção da lesihamniose tegumentar Americana no estado do Paraná, sul do Brasil. Revista da Sociedade Brasileira de Medicina Tropical, Uberaba, v. 42, p. 509-514, 2009. https://doi.org/10.1590/S0037-86822009000500007

MURBACK, N. D. N.; NASCIMENTO, R. A. F.; DORVAL, M. E. M. C.; HANS FILHO, G.; NAKAZATO, K. R. O. Leishmaniose tegumentar americana: estudo clínico, epidemiológico e laboratorial realizado no Hospital Universitário de Campo Grande, Mato Grosso do Sul, Brasil. Anais Brasileiros de Dermatologia, Rio de Janeiro, v. 86, n. 1, p. 55-63, 2011.

NAME, R. Q.; BORGES, K. T.; NOGUEIRA, L. S. C.; SAMPAIO, J. H. D.; TAULI, P. L.; SAMPAIO, R. N. R. Estudo clínico, epidemiológico e terapêutico de 402 pacientes com leishmaniose tegumentar americana atendidos no Hospital Universitário de Brasília, DF, Brasil. Anais Brasileiros de Dermatologia, Rio de Janeiro, v. 80, p. 249-254, 2005.

NISHIOKA, S. A.; FERREIRA, M. S.; MACHADO, M. I.; SILVA, A. M.; ROCHA, A.; COSTA-CRUZ, J. M.; GONÇALVES, M. R. F. An outbreak of cutaneous leishmaniasis. Revista da Sociedade Brasileira de Medicina Tropical, Uberaba, v. 21, n. 4, p. 209, 1988. https://doi.org/10.1590/S0037-86821988000400010

OLIVEIRA, C. C. G.; LACERDA, H. G.; MARTINS, D. R.; BARBOSA, J. D. A.; MONTEIRO, G. R.; QUEIROZ, J. W. Changing epidemiology of American cutaneous leishmaniasis (ACLS) in Brazil: a disease of the urban - rural interface. Acta Tropica, Basel, v. 90, n. 2, p. 155-162, 2004.

https://doi.org/10.1016/j.actatropica.2003.11.011

PACE, D. Leishmaniasis. The Journal of Infection, London, v. 69, p. 510-518, 2014. https://doi.org/10.1016/j.jinf.2014.07.016

PASTORINO, A. C.; JACOB, C. M.; OSELKA, G. W.; CARNEIRO-SAMPAIO, M. Leishmaniose visceral: aspectos clínicos e laboratoriais. Jornal de Pediatria, Porto Alegre, v. 78, p. 120-127, 2002.

https://doi.org/10.1590/S0021-75572002000200010

https://doi.org/10.2223/JPED.820

PAULA, M. B. C.; RODRIGUES, E. A. S.; SOUZA, A. A.; REIS, A. A.; PAULA, F. P.; PAJUABA NETO, A. A.; LIMONGI, J. E.. Primeiro encontro de Lutzomyia longipalpis (Lutz \& Neiva, 1912) na área urbana de Uberlândia, MG, concomitante com o relato de primeiro caso autóctone de leishmaniose visceral humana. Revista da Sociedade Brasileira de Medicina Tropical, Uberaba, v. 41, n. 3, p. 304-305, 2008. https://doi.org/10.1590/S0037-86822008000300016

PAULA, M. B. C.; SOUZA, A. A.; REIS, A. A.; LIMONGI, J. E.; PAJUABA NETO, A. A.; RODRIGUES, E. A. S. Survey of sandfly fauna (Diptera: Psychodidae) in Uberlândia, Minas Gerais State, Brazil, 2003 - 2004.

Revista do Instituto de Medicina Tropical de São Paulo, São Paulo, v. 55, n. 2, p. 85-89, 2013. https://doi.org/10.1590/S0036-46652013000200004

RODRIGUES, E. A. S.; ANDRADE-FILHO, J. D.; LIMONGI, J. E.; PAULA, M. B. C. Sandfly fauna (Diptera: Psychodidae) in Parque do Sabiá complex, Uberlândia, Minas Gerais, Brazil. Revista do Instituto de Medicina Tropical de São Paulo, São Paulo, v. 53, n. 5, p. 255-258, 2011. https://doi.org/10.1590/S003646652011000500003

SKRABA, C. M.; MATSUBARA, F. M,.; ZANZARINI, P. D.; VENAZZI, E. A. S.; FERNANDES, A. C. S.; SILVEIRA, T. G. V.; LONARDONI, M. V. C.; ARRAES, S. M. A. A. Diagnóstico e acompanhamento de pacientes suspeitos de leishmaniose tegumentar americana. In: IV FÓRUM DE EXTENSÃO E CULTURA DA UEM: PERSPECTIVAS DA EXTENSÃO UNIVERSITÁRIA E DA PRESTAÇÃO DE SERVIÇOS, 10., 2006, Maringá. Arquivos Mudi. Maringá/PR, 2006. 
STRIETER, R. M.; REMICK, D. G.; WARD, P. A.; SPENGLER, R. N.; LYNCH, J. P.; LARRICK, J.;

KUNKEl, S. L. Cellular and molecular regulation of tumor necrosis factor-alpha production by pentoxifylline. Biochemical and Biophysical Research Communications, Orlando, v. 155, p. 1230-1236, 1988.

https://doi.org/10.1016/S0006-291X(88)81271-3

TOLEZANO, J. E. Ecoepidemiological aspects of American cutaneous leishmaniasis in the state of São Paulo, Brazil. Memórias do Instituto Oswaldo Cruz, Rio de Janeiro, v. 89, p. 427-434, 1994. 